\section{VENOMOUS SNARES.-II}

The American species of Elapids known to be poisonous are the Harlequin Snake, or Bead Snake (Elaps fulvus), and the Sonoran Coral Snake (Elaps euryxan thus)

The Harlequin Snake is found in Virginia, Georgia, Florida, Alabama, North and South Carolina, and Mississippi, and north along the Mississippi, Missouri, and Ohio Rivers. In southern Texas, too, it occurs in many localities. This snake is said to be very gentle and mild in disposition. Its favorite haunt is supposed to be underground in sweet potato fields, where it is frequently unearthed by laborers in harvesting. It food consists chiefly of other snakes and various kinds of reptiles. One specimen found had swallowed another snake as long as itself; while, in addition, it had a garter snake about half digested. The Harlequin Snake is described as having a ground color of red with numerous black ring and intermediate spaces of yellow. The tail is alternately black and yellow.

A rather curious variety of rattlesnake is the Crotalus cerastes, which, as its name indicates, is dis tinguished by a horn over each eye. Horned rattlesnakes are most ven-

A rattlesnake which goes by the Indian name of Massasauga is on of the smail but very venomous rattlesnakes which inhabit the pralries in the western United States and territories. The most prominent of these rattlers is the prominent of these rattlers is the
Crotalaphorus tergeminus (Sis-

trurus catenatus). One of the characteristics of the Massasauga is the top of the head, which is covered with regular plates just as in harmless serpents, and not with scales as in most rattlesnakes. The pit between the eyes and the nose, however, is present as in all Crotalide. The Massasauga snakes are of dark, blotched coloration, and are rarely more than one or two feet long. Sometimes they are called sidewipers and sideliners from their habit of wriggling sidewise A few words on the structure of a rattlesnake's rattle may not be without interest. Briefly described, the rattle consists of a number of hollow, horny rings, somewhat like quill in substance, and interlocked with one another, while they are so elastic as to permit of a considerable amount of motion between them. These rings are not indicative of age, as has been supposed, since in some years several appear, while in others only one ring may be developed. Though there is a great variety of color developed. Though there is a great variety of color
in rattlesnakes, this feature can in most cases be in rattlesnakes, this feature can in most cases be
used as a means of determining the species, other used as a means of determining the species, othe distinctive characteristics being found in the arrange

The dread which even the bare thought of receiving a charge of the deadly venom inspires, is fortunat somewhat diminished by the well-known fact that this somewhat dimished by the well-known fact that this snake always "rattles" before striking. There has been a great deal written as to the reasons which
cause them to "sound the alarm." The old theory cause them to "sound the alarm." The old theory
was that the "rattling" was intended to warn the prey of their approach. This, however, seems alto

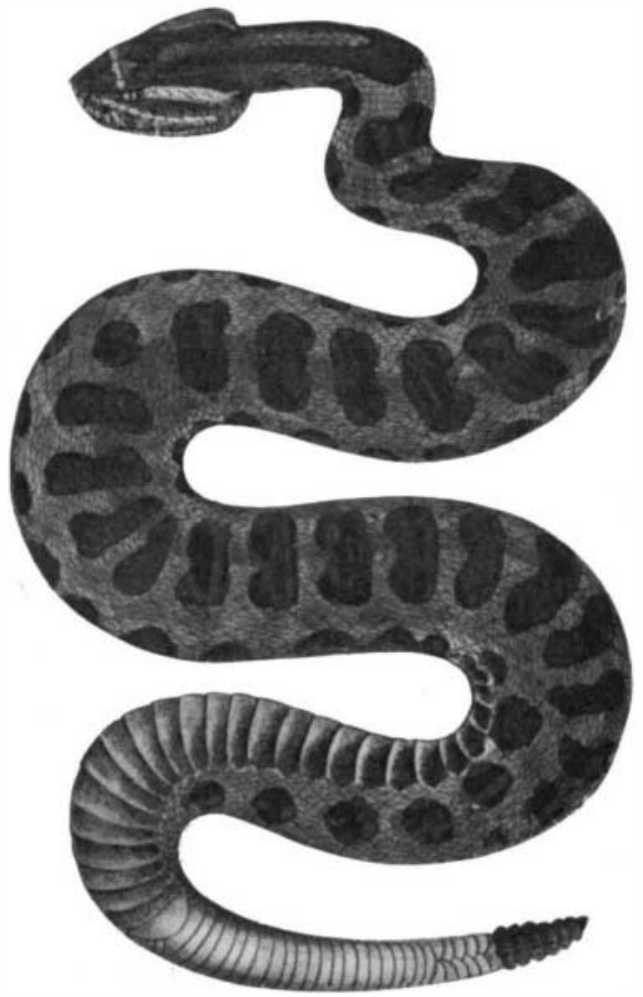

MASSASAUGA (AFTER HOLBROOK). gether too charitable a view to take, for it is quite natural to supose that the snake would keep as quiet as possible when lying in wait for food, lest it should frighten away the approaching animals upon which it supposedly depends for its sustenance. Another view, and a more plausible one, is that, as the cobra expands its frill and the puif-adder swells and hisses, so the rattlesnake sounds its rattle for the purpose of alarming any antagonist-be it man, beast, or bird-who may design an attack. Thus it becomes a weapon of defense-perhaps an expression of fear. The snake, not being endowed with human thought, would hardly realize that in making itself known to its enemies, it was betraying itself, while by remaining quiet, its presence mighí be overlooked: Another

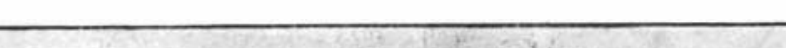

present, or rather where it was not found before it was exterminated. Still, the area inhabited by more than one species of Crotalus is comparatively limited. It may not be out of place to tell here something of the Fer-de-Lance, the deadly snake of Martinique, which is said to have been all but exterminated by the recent volcanic eruptions. This serpent may be regarded as a yellow viper of the family Crotalide, designated zoologically by the term Craspedocephalus (or Bothrops) lanceolatus. The Fer-de-Lance is .rom (or Bothrops) lanceelatus. The rom 5 to 7 feet long, and is sald to be capable of making considerable springs when in pursuit of prey or of
some object by which it has been irritated. Its bite is fatal, the only antidote seeming to be, as in the case of bites of other venomous snakes, whisky or other ardent spirits. The serpent infests sugar plantations in the West Indies, and is dreaded alike by man and beast. by man and beast. The tail ends in ly against objects, but does not ratly against objects, but does not rat-
tle. How deadly is the Fer-deLance may be gathered from the description of a writer in Harper's Magazine: "If by some rare chance you encounter in the island [of Martinique] a person who has lost an arm or a pen you can be almost an arm or a leg, you can be almost certain you are looking at a victim
of the Fer-de-Lance-the serpent whose venom putrefies living tissue."

( To be continued.)

Protecting the Sponges.

The use of the "skafander" has been abolished by Samos, Crete, Cyprus, Tunis, and Egypt. Now common belief is that the rattle is sounded as a means kind. Prof. Samuel Aughey, in an article on the "Rattle of the Rattlesnake," confirms this belief. He says he once saw a number of hogs attacking a rattlesnake. The snake at once commenced rattling, and three other snakes almost immediately came to the rescue, but the hogs were victorious. and all the snakes were observations, believe that the true function of the rattle is to bring the sexes together for mating, while still others affirm that its principal use is to frighten and paralyze the victim into submission, thus acting as a kind of "charm." There is yet one more theory to account for the use of the rattle, namely, to ward off disturbers that cannot serve as food, and thus prevent a useless expenditure of venom!-surely fixing this snake as a strict economist, if true.

These theories may all be partly correct. The phenomenon may perhaps be most easily explained by accepting and applying Herbert Spencer's suggestion regarding the wagging of a dog's tail, i. e., that it is an escape of nervous force which is restrained from any other mode of expression at the moment.

No species of rattlesnake occurs in any of the West Indian islands proper. Several species are found in the United States, as pointed out, and indeed there are but fow localities here where this snake is not

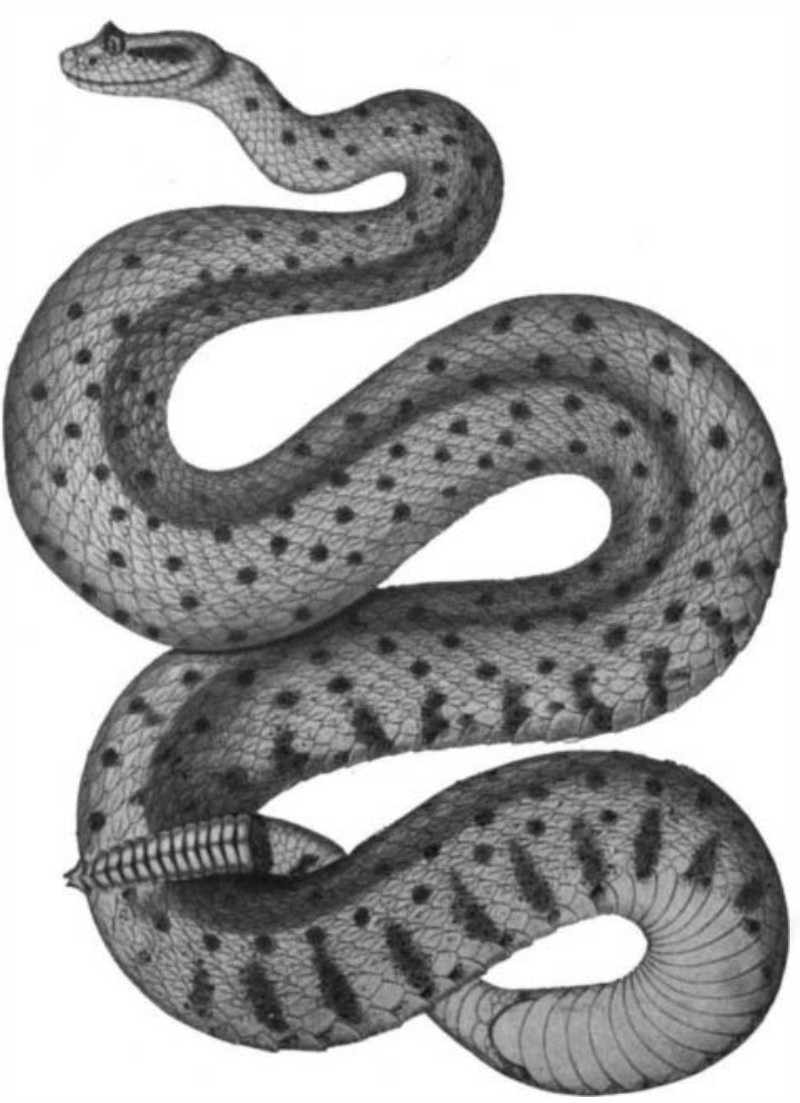

HORNED RATTLESNARE (CROTALUS CERASTES).
THE WEST INDIAN FER DE-LANCE. of bringing to its assistance other snakes of its own killed. Some authorities, who have made careful Turkey and Greece have followed
suit. The skafander is a device by which a diver can remain under water for about an hour. $\mathrm{He}$ is thus enabled to comb the bottom of the sea with a thoroughness that has almost exterminated sponges in many parts. The employment is its own punishment; for the diver usually dies of palsy of the lower extremities. tremities. The law now steps in to assist nature in
protecting the sponges. In addition to the skafander the natives resort to harpooning, primitive diving apparatus, and dredging.

The frequency with which old pipes made of clay, wood, and metal have been found in England, Ireland, Germany, Switzerland and France, has led archæologists to the belief that the ancients may have smoked. The belief receives some color from passages in ancient authors. Herodotus remarks that the inhabitants of the Aroxes Islands, supposed to be the modern Volga, "were wont to throw piles of fruit on a fire and then to inhale the vapor, with the result that they became as drunk as ever the Greeks became after drinking wine, and the more fruit they threw on the fire the more drunk they became." Pomponius Mela talks in a similar strain of certain Thracian tribes. Pliny asserts that the vapor of plants was used to cure diseases, and says that in some instances it was even inhaled through a tube.

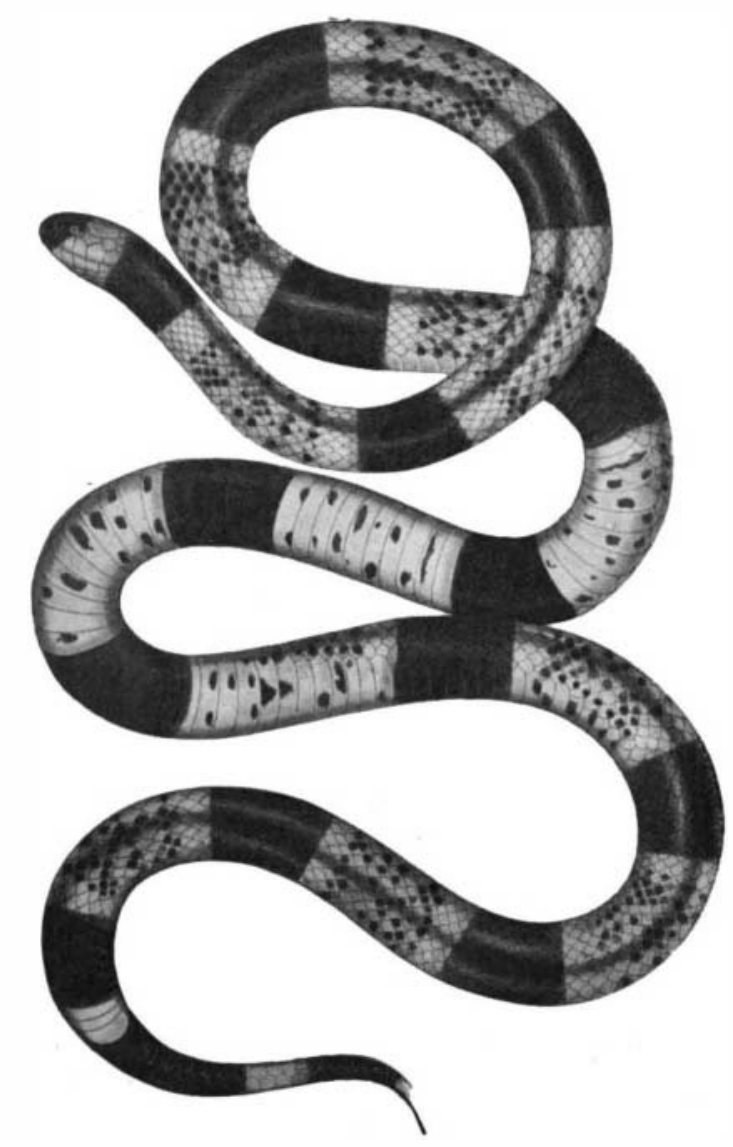

HARLEQUIN SMARE. 